\title{
Preparation and Evaluation of Some Weaning Foods Made from Rice and Legumes
}

\author{
Tesby Mohamed Rashad Lotfy, Asteer Victor Abd Elnoor, Marwa Zaki Mahfouz, \\ Asmaa Khaled Shafik \\ Department of Home Economics, Faculty of Specific Education, Alexandria University, Alexandria, Egypt
}

\begin{abstract}
Weaning is a gradual process of introducing solids foods to an infant's diet, alongside breast milk from the age of six months, since the breast feeding along cannot meet the infant nutritional requirement. in this study three composite foods were prepared from rice and some legumes (roasted soybean, roasted peanut and roasted chickpeas) ratio 70:30. The formulations were made to meet the greatest amino acid scores, the desired amount of energy and protein according to the FAO/WHO recommendation for infants. Concentrations of energy, protein, amino acid, phytates, trypsin inhibitor, tannins and protein digestibility were determined by standard methods. The proximate chemical composition results indicated that the moisture $(10.01 \%$ to $11.77 \%)$, as water was added during cooking, protein $(7.90 \%$ to $10.70 \%)$, ash $(0.99 \%$ to $4.52 \%)$ crude fiber $(0.91 \%$ to $1.04 \%)$, energy $(344.3 \mathrm{kcal} / 100 \mathrm{~g}$ to $400.3 \mathrm{kcal} / 100 \mathrm{~g})$, fats $(0.88 \%$ to $11.82 \%)$ and carbohydrates were $(61.99 \%$ to $74.0 \%)$. the levels of protein in blends of weaning food were higher than the control. the results of antinutrition factors ranges phytic acid $(3.90$ to $4.52 \mathrm{mg} / 100 \mathrm{~g})$, trypsin inhibitor $(0.39$ to $0.47 \mathrm{tiu} / \mathrm{mg})$ and tannins (17.12 to $19.50 \mathrm{mg} / 100 \mathrm{~g}$ ). heat processing and cooking of the blends resulted in low levels of anti-nutrition and higher in vitro protein digestibility ranged from $(83.30$ to $87.59 \%$ ) of the weaning food blends respectively. the result of the sensory evaluation showd that the best blend was contained rice/peanut and rice/ chickpeas but rice/ soybean was low in the acceptability. this study recommends that mix cereals with legumes to achieve complementation of amino acids and consequent improvement in protein quality.
\end{abstract}

Keywords: rice, soybean, peanut, chickpeas, chemical composition, protein digestibility, anti-nutrition and sensory evaluation.

\section{INTRODUCTION}

Breast milk is the ideal food for infants during the first six months of life, In spite of its superiority. Breast milk cannot provide all of the nutrients and calories that allow infants to thrive after 6 months of life (Gairdner and Pearson, 1998). After six months of breast feeding, supplementary feeding is essential because breast-milk alone cannot provide enough nutrients and energy for growing children. (Ijarotimi and Famurewa, 2006 and Udensi et al., 2012).

Weaning is a period of transition for the infant during changes diet in terms of consistency and source (Xia et al., 2018). The child is gradually weaned into a semi solid food which is generally described to be digestible, having high energy density and low bulk (Onweluzo and Nwabugwu, 2009).

A variety of commercially available complementary foods with high nutritional value, which are used directly to prepare gruels. However, in many developing countries, these products are beyond the economic means of most families (Njongmeta et al,. 2003). So, mothers use traditional gruels-water suspensions of maize or sorghum, as complementary foods for infants. These gruels usually have low energy density, poor protein, vitamin and mineral contents (Zaker, 2017). Thus, protein-energy malnutrition is a common problem among infant and children in the poor socioeconomic groups of developing countries.
Cereals, the main source of calories in the diet, are adequate in methionine and cysteine and are a good source of B-complex vitamins but limiting in lysine (Gulzar, 2011). Cereals are deficient in lysine but have sufficient Sulphur containing amino acids which are limited in legumes whereas legumes are rich in lysine (Iqbal et al,. 2006).

Rice is a staple food of the world and being a major source of carbohydrates over half the world's population (Tran et al., 2005 and Megat Rusydi et al., 2011). Rice is belonging to the grass family of Gramineae and related to other grass plants such as wheat, oats and barley which produce grains for food (Arber, 2010). Rice also provides nutritionally significant amounts of thiamin, riboflavin, niacin and zinc with lesser amounts of other micronutrients (Megat Rusydi et al., 2011).

In this research work, efforts were made and develop a weaning foods based on flour of rice with some legume (soybean, peanut and chickpeas) blended together in the ratio 70/30. The purpose of the study aims to producea low-cost weaning foods from easily available Resources that is nutritionally adequate, acceptable and easily available from rice and some legumes Thus, a weaning foods rich enough in energy and proteins for infants was obtained by proximate chemical analysis and antinutritional factors. 


\section{MATERIALS AND METHODS}

\section{Materials}

The seeds of Egyptian rice, soybean, peanut and chick peas were obtained from the local market, Alexandria, Egypt. The seeds were kept at room temperature in air tight containers.

\section{Preparation and conditioning of rice for using} in weaning foods

Rice samples were washed with sufficient tap water. Then, samples were soaked in distilled water for 72 hours with the water was changed in every 24 hr (Megat Rusydi et al., 2011). The rice was air dried at room temperature for 8 hours, and then dehulled, followed by milling and sieving. The flour was then packaged. The samples were contained in plastic sealed and stored in refrigerator at $4^{\circ} \mathrm{C}$.

\section{Preparation and conditioning of legume flours}

Soya beans were thoroughly sorted to remove all extraneous covers. Then soaked in tap water for 6 hours and washed several times with more water. Peanuts and chickpeas were manually cleaned to remove debris. Split and discoloured seeds were discarded, legumes were roasted in an oven at $70^{\circ} \mathrm{C}$ for 30 minutes, (Soaking and roasting were intended to remove the beany flavor). Followed by milling and sieving. The flour was packaged in dry pack. (Isaac and Koleosho, 2012).

\section{Weaning foods formulation using rice and} some legumes

Weaning foods were formulated using white rice and some legumes including soybean, peanut and chickpeas, respectively with a ratio 70:30 where, $70 \%$ rice with $30 \%$ one of the tested used legumes.

\section{Weaning foods formulation}

Cooked blends (gruels) were prepared. An initial flour paste was made mixing $100 \mathrm{~g}$ of flour cereal with legumes and $200 \mathrm{~mL}$ of deionized water. To the paste, $700 \mathrm{~mL}$ of boiling 30 deionized Water was added and mixed well. Flour-water slurries were cooked in a boiling water bath until the temperature reached $100^{\circ} \mathrm{C}$. Cooking was continued an additional $15 \mathrm{~min}$. the result obtained to gruels soft and acceptability color (Griffith et al, 1998).

\section{Sensory evaluation of prepared weaning food}

The sensory characteristics were evaluated according to Hooda and Jood (2005) hedonic scale by mothers in health offices and children aged from 6 to 24 months by facial expressions. The Evaluated characteristics including color, odor, texture, flavor and the overall acceptability. The 9- point hedonic scale with a scale ranging from 1 (Extremely dislike) to 9 (Extremely like) was used to evaluate the sensory attributes.

\section{Proximate chemical composition}

The proximate chemical composition including moisture, crude protein, total fats, crude fibers and carbohydrate of weaning foods were analyzed according to (Anderson, 2007).
Caloric values were calculated from the sum of the percentages of crude protein and total carbohydrates multiplied by a factor of $4(\mathrm{Kcal} / \mathrm{g})$ plus the crude fat content multiplied by $9(\mathrm{Kcal} / \mathrm{g})$ according to (Zambrano et al., 2004).

\section{Minerals}

$\mathrm{Fe}, \mathrm{Ca}, \mathrm{Mg}, \mathrm{Zn}$, Were determined using Atomic Absorption Spectrophotometer (Shimadzu model AA- 6650) as described in AOAC Official methods with (Anderson, 2007).

9. Phytochemical characterization (antinutritional factors)

Trypsin inhibitor (TrI) was extracted and determined according to (Hamerstrand et al., 1981). A sample $(1.00 \mathrm{~g})$ was extracted with $50 \mathrm{ml}$ of $(0.01 \mathrm{~N}) \mathrm{NaOH}$ (the $\mathrm{pH}$ adjusted, when required, to 8.4-10.0) for $3 \mathrm{hr}$. Stirring sufficient to keep the sample in suspension was maintained. This suspension was then diluted so that $2 \mathrm{~mL}$ of the sample extract inhibited $40-60 \%$ of the trypsin used as a standard in the analysis. The appropriate dilutions were determined from either a preknowledge of the heat treatment of the sample or from a urease analysis, which reflects the heat treatment of the sample. If the value obtained did not fall within the specified range of inhibition, the analysis was repeated with the correct dilution. To each of four test tubes, 2-mL aliquots of the diluted sample extract were added with a wide-tip pipette. A fifth tube was prepared for the trypsin standard by adding $2 \mathrm{~mL}$ of distilled water. To three of the four tubes containing the sample extract and the tube containing distilled water, $2 \mathrm{~mL}$ of the trypsin solution was added, and the tubes were placed in a constant temperature bath $\left(37^{\circ} \mathrm{C}\right)$ for $10 \mathrm{~min}$. Five milliliters of BAPA solution (pre-warmed to $37^{\circ} \mathrm{C}$ ) was rapidly blown into each tube. The contents were stirred immediately on a vortex mixer, and the tubes were replaced in the constant temperature bath. The reaction was terminated exactly $10 \mathrm{~min}$ later by blowing in $1 \mathrm{~mL}$ of $30 \%$ acetic acid with immediate mixing with a vortex mixer. A sample blank (the fourth tube containing sample extract) was prepared by the same procedure except that the trypsin solution was added after the reaction was terminated by the addition of acetic acid. The absorbance of each solution was determined at $410 \mathrm{~nm}$ against the sample blank. Values obtained from each of the three sample extracts were subtracted from the trypsin standard. These values were averaged, and the trypsin inhibitor content was determined from the following equation (1):

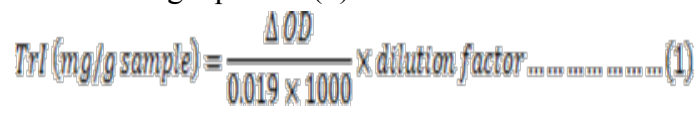

Tannin was determined according to (Ahmed et al., 2006). While phytate was determined According to (Davies and Reid, 1979). 


\section{Determination of Protein digestibility}

Protein digestibility was determined using enzymatic hydrolysis (pepsin and pancreatin), then the nitrogen contents were analyzed by the microKiel-dahl method. The protein digestibility of samples was calculated by subtracting undigested protein from crude protein of the blends (Prakash and Prakash, 1999).

\section{Amino acid composition}

Determination of amino acid contents of the prepared weaning meals was done at Regional Center for Food and Feed, Cairo, Egypt by using amino acid analyzer (biochrom30) according to (Otter, 2012).

\section{Statistical analysis}

The statistical analysis was performed using the SPSS 25.0 software (Statistical Package for Social Sciences, USA). Analysis of variance (ANOVA) of the data was conducted and means property values were separated $(p \leq 0.05)$ with LSD test for the property values. Differences were considered significant at $\mathrm{p} \leq 0.05$.

\section{RESULTS AND DISCUSSION}

\section{Sensory properties}

The results of sensory analysis of the formulated weaning food samples are shown in Table (1). Sensory evaluation was studied by children aged from 6 to 24 months, as well as mothers $(n=50)$ in nurseries and health offices. The data showed that there were significant differences $(\mathrm{P} \leq 0.05)$ among the prepared weaning food in color, texture, taste, and acceptances. Color is less important for babies, mothers would play a vital role for any complementary food to be successfully utilized and accepted. However, the control and rice/soybean blend was the least scored in color, texture, taste, and acceptances assessment and there are significant differences between it and other blends. Followed in the ascending order by the rice/peanuts in color and odor with score 4.06 , and 3.72 , respectively then rice/chickpea with score 4.28 and 4.08. Moreover, there is no significant difference between the rice/chickpea and rice/peanut weaning in other parameters including texture, and taste and over acceptance.

\section{Proximate chemical composition of prepared weaning food \\ Table (2) shows the proximate composition} analysis of blends with ratio of 70:30 and compared with control rice. The results showed that the moisture content decreased when the rice mixing with peanuts compared with rice/soybeans, while there is no significant difference between control rice and rice/peanuts with 10.24 and 10.01, respectively. However, the rice/soybeans have a highest moisture content with (11.77\%). Followed in the descending order by rice/chickpea with $(10.97 \%)$. The protein contents were increased with blend the rice with legumes than control rice only. The rice/soybean with $(10.70 \%)$, was the highest protein contents among all prepared blends. Then the rice/chickpeas have a moderately protein content of $10.21 \%$. In addition, the mixture of rice / peanuts was the least percent of protein $(7.90 \%)$. The ash contents were increases when the rice blend with legumes. There are significant differences $(\mathrm{P} \leq 0.05)$ among all prepared weaning food. The ash contents were ranged from 0.40 to $2.23 \%$. The fiber content in the wide range in all blends and control. However, there are significant differences $(\mathrm{P} \leq 0.05)$ between control rice and its blends with legumes. In addition, there is no significant differences among all blends with 1.14, 0.91 and $1.04 \%$ for rice/soybean, rice/chickpea, and rice/peanut, respectively. The proportion of fat in blends was balanced with the needs of the child in weaning phase where the proportion of fat ranged from $0.88 \%$ to $11.82 \%$. At all events, the fat contents of all blends were decreased compared to control rice except the rice/peanuts blend the fat was increased about control rice that is due to the high fat content of peanuts. The highest percentage of carbohydrate was in the Control $83.93 \%$ while the lowest carbohydrate ratio was in the rice mixture with chickpea $64.71 \%$. Followed in the descending order by rice/soybeans $74.0 \%$.

Walker (1990) suggested an energy density of $370 \mathrm{kcal} / 100 \mathrm{~g}$ as the minimum desirable level for infant weaning foods. The calculated energy densities obtained for the experimental blends ranged from 344 to $400.3 \mathrm{kcal} / 100 \mathrm{~g}$ and were comparable to those reported by other researchers (Pedersen et al. 1989).

Table 1: Sensory properties of weaning foods rice - legumes blends (by mothers)

\begin{tabular}{lccccc}
\hline Blends & \multicolumn{1}{c}{ Color } & \multicolumn{1}{c}{ Odor } & \multicolumn{1}{c}{ Textures } & Taste & Acceptance \\
\hline Control rice & $2.65^{\mathrm{c}} \pm 1.49$ & $2.76^{\mathrm{bc}} \pm 1.50$ & $3.50^{\mathrm{bc}} \pm 2.13$ & $1.99^{\mathrm{b}} \pm 0.76$ & $1.60^{\mathrm{b}} \pm 0.70$ \\
\hline Rice /soybeans & $2.60^{\mathrm{c}} \pm 1.48$ & $2.26^{\mathrm{c}} \pm 1.16$ & $3.52^{\mathrm{bc}} \pm 2.14$ & $1.68^{\mathrm{b}} \pm 0.74$ & $1.66^{\mathrm{b}} \pm 0.77$ \\
\hline Rice /Peanuts & $4.06^{\mathrm{b}} \pm 2.32$ & $3.72^{\mathrm{b}} \pm 1.99$ & $5.20^{\mathrm{ab}} \pm 2.72$ & $6.28^{\mathrm{a}} \pm 3.32$ & $6.44^{\mathrm{a}} \pm 3.36$ \\
\hline Rice / Chickpeas & $4.28^{\mathrm{a}} \pm 2.02$ & $4.08^{\mathrm{a}} \pm 1.54$ & $5.34^{\mathrm{a}} \pm 2.49$ & $6.22^{\mathrm{a}} \pm 2.61$ & $6.46^{\mathrm{b}} \pm 2.86$ \\
\hline
\end{tabular}

Values are mean of three replicates and are given as mean \pm standard error. Different letters in the same row indicate significant differences according to LSD test $(\mathrm{P} \leq 0.05)$. 
Table 2. Chemical composition of weaning foods rice-legumes blends

\begin{tabular}{lcccc}
\hline Components & Control Rice & Rice/soybean & Rice/peanut & Rice/ chickpea \\
\hline Moisture & $10.24^{\mathrm{c}} \pm 0.09$ & $11.77^{\mathrm{a}} \pm 0.31$ & $10.01^{\mathrm{c}} \pm 0.26$ & $10.97^{\mathrm{b}} \pm 0.16$ \\
\hline Protein & $1.22^{\mathrm{d}} \pm 0.15$ & $10.70^{\mathrm{a}} \pm 0.09$ & $7.90^{\mathrm{c}} \pm 0.01$ & $10.21^{\mathrm{b}} \pm 0.09$ \\
\hline Ash & $0.40^{\mathrm{d}} \pm 0.01$ & $2.23^{\mathrm{b}} \pm 0.08$ & $4.52^{\mathrm{a}} \pm 0.05$ & $0.99^{\mathrm{c}} \pm 0.09$ \\
\hline Fibers & $1.30^{\mathrm{b}} \pm 0.02$ & $1.14^{\mathrm{a}} \pm 0.21$ & $1.04^{\mathrm{a}} \pm 0.18$ & $0.91^{\mathrm{a}} \pm 0.11$ \\
\hline Fats & $3.16^{\mathrm{b}} \pm 0.01$ & $0.88^{\mathrm{d}} \pm 0.13$ & $11.82^{\mathrm{a}} \pm 0.24$ & $1.22^{\mathrm{c}} \pm 0.15$ \\
\hline Carbohydrates & $83.93^{\mathrm{a}} \pm 0.08$ & $74.0^{\mathrm{ab}} \pm 0.01$ & $61.99^{\mathrm{bc}} \pm 0.50$ & $66.43^{\mathrm{bc}} \pm 0.09$ \\
\hline Calories & $368.0^{\mathrm{f}} \pm 0.01$ & $344.3^{\mathrm{h}} \pm 0.01$ & $400.3^{\mathrm{d}} \pm 0.01$ & $354.0^{\mathrm{g}} \pm 0.01$
\end{tabular}

Values are mean of three replicates and are given as mean \pm standard error. Different letters in the same row indicate significant differences according to LSD test $(\mathrm{P} \leq 0.05)$.

\section{Minerals content}

Mineral contents were analyzed for studied of weaning food presented in Table (3) compared with the control rice. The results found that the mineral concentration was decreased after treatment with boil, roasting and grinding. The calcium $(\mathrm{Ca})$ was increased in all blends compared with the control. The highest percentage of $\mathrm{Ca}$ was rice/soybeans $1.66 \% /$. The iron $(\mathrm{Fe})$ is the most essential mineral to child for hemoglobin construction, the Fe was increased with mixing with legumes. The highest percentage of $\mathrm{Fe}$ were rice/soybean $2.17 \%$. The Magnesium ( $\mathrm{Mg}$ ) was increased in all blends compared with the control. The zinc was increased in rice/soybean and rice/ peanut blends $0.62 \%$, $0.49 \%$ and decreases in rice/ chickpeas blends 0.21 compared with the control.

\section{Anti-nutritional factor}

Anti-nutrition factors contents including phytic acid, tannins and trypsin inhibitor was presented in Table (4) for the ratio of 70:30, respectively. The phytic acid in the studied weaning foods were ranged from 3.90 to $4.52 \mathrm{mg} / 100 \mathrm{~g}$ the lowest percentage of phytic acid were rice/chickpeas. However, there is no clear significant difference between blends. Roasting of legumes also reduced the phytic acid. The inherent phytase activity on cereals is believed to be activated during treatment (Sharma et al., 2018).
On the other hand, some authors reported that phytic acid contents were unaffected or increased after heat treatments (Embaby, 2010).

Trypsin inhibitor are heat labile and can be partially and completely denatured when exposed to elevated temperature. The values of trypsin inhibitor in weaning food (low activity of trypsin inhibitor enzyme) ranged from 0.39 to 0.47 that is due to the cooking, roasting and grinding for used cereal and legumes. Wang et al., (1997) reported that steam blanching of legume resulted in higher reduction in trypsin inhibitor activity than using water blanching. However, Hamerstrand et al., (1981) reported that microwave cooking destroyed trypsin inhibitors to a degree similar to that observed in six legumes cooked using the conventional method.

The total tannins were determined in weaning food as anti-nutritional factor. The most tannins are located in seed coats (skin) and hulls are practically tannin free (Naczk and Shahidi, 2004). The control have the lowest value of tannins $(16.25 \mathrm{mg} / 100 \mathrm{~g})$. Followed in the ascending order by rice/soybeans with $17.12 \mathrm{mg} / 100 \mathrm{~g}$ and then rice/chickpeas with $19.50 \mathrm{mg} / 100 \mathrm{~g}$. The reduction in tannins contents during roasting treatments might be due to the loss of compounds while treating at a high temperature (Nithya et al., 2007).

Table 3. Minerals composition of weaning food cereal - legumes blends

\begin{tabular}{lcccc}
\hline Components(mg/l) & Control Rice & Rice/ soybean & Rice/ peanut & Rice /chickpeas \\
\hline $\mathrm{Mg}$ & $4.01^{\mathrm{e}} \pm 0.06$ & $11.98^{\mathrm{a}} \pm 0.11$ & $9.66^{\mathrm{b}} \pm 0.11$ & $5.04^{\mathrm{c}} \pm 0.07$ \\
\hline $\mathrm{Ca}$ & $0.52^{\mathrm{c}} \pm 0.05$ & $1.66^{\mathrm{a}} \pm 0.11$ & $0.59^{\mathrm{b}} \pm 0.10$ & $0.60^{\mathrm{b}} \pm 0.10$ \\
\hline $\mathrm{Zn}$ & $0.36^{\mathrm{bc}} \pm 0.01$ & $0.62^{\mathrm{a}} \pm 0.20$ & $0.49^{\mathrm{ab}} \pm 0.15$ & $0.21^{\mathrm{c}} \pm 0.10$ \\
\hline $\mathrm{Fe}$ & $2.01^{\mathrm{b}} \pm 0.14$ & $2.17^{\mathrm{a}} \pm 0.07$ & $2.04^{\mathrm{b}} \pm 0.14$ & $0.69^{\mathrm{c}} \pm 0.28$ \\
\hline
\end{tabular}

Values are mean of three replicates and are given as mean \pm standard error. Different letters in the same row indicate significant differences according to LSD test $(\mathrm{P} \leq 0.05)$.

Table 4. Anti-nutritional factor and Protein digestibility of weaning foods cereal - legumes blends

\begin{tabular}{lcccc}
\hline $\begin{array}{l}\text { Anti-nutritional factor } \\
\text { Protein digestibility }\end{array}$ & Control/rice & Rice/soybean & Rice/peanut & Rice/chickpeas \\
\hline Phytic acid (mg/100g) & $4.40^{\mathrm{b}} \pm 0.10$ & $4.43^{\mathrm{b}} \pm 0.10$ & $4.52^{\mathrm{a}} \pm 0.21$ & $3.90^{\mathrm{c}} \pm 0.19$ \\
\hline Tannins (mg/100g) & $16.25^{\mathrm{d}} \pm 0.09$ & $17.12^{\mathrm{c}} \pm 0.03$ & $19.26^{\mathrm{b}} \pm 0.03$ & $19.50^{\mathrm{a}} \pm 0.05$ \\
\hline Trypsin inhibitor(TIU/mg) & $0.40^{\mathrm{b}} \pm 0.04$ & $0.47^{\mathrm{a}} \pm 0.03$ & $0.41^{\mathrm{b}} \pm 0.02$ & $0.39^{\mathrm{bc}} \pm 0.02$ \\
\hline Protein digestibility $(\%)$ & $85.55^{\mathrm{d}} \pm 0.02$ & $83.30^{\mathrm{c}} \pm 0.02$ & $87.32^{\mathrm{b}} \pm 0.02$ & $87.59^{\mathrm{a}} \pm 0.02$ \\
\hline
\end{tabular}


Also, the loss of tannins may be due to the degradation or interaction with other components of seeds, such as proteins, to form insoluble complexes (Embaby, 2010). Osman (2007) reported a significant increase in tannins contents in cooked, autoclaved and roasted Dolichols lablab bean. Additionally, Embaby( 2010) found that the autoclaving, ordinary cooking and microwave cooking didn't affect tannins contents in bitter lupine seeds.

Protein is a inextricable component to the human diet. Without proteins, cells would be unable to function properly, our organs and tissues would not be able to perform their duties and our bodies would wither away.

There are many sources of protein available to children. FAO/WHO has adopted a proteincorrected amino acid, as the preferred method of measuring the value of protein in human nutrition (Hulse 1989; Wondimu and Malleshi 1996).

The results of protein digestibility were ranged from $83.30 \%$ to $87.59 \%$, the highest percentage of protein digestibility was rice/chickpeas. The studied formulated weaning blends had good digestibility because their values were high than $75 \%$. The rice/chickpeas have the maximum digestibility with $87.59 \%$ and there is no significant difference with rice/peanut with $87.32 \%$. Followed in the descending order by the control rice $85.55 \%$ then rice/soybean with $83.30 \%$.

\section{Amino acid content}

Amino acids analysis showed that the protein from plant sources contained nutritionally available quantities of most of the essential amino acids but was low in sulphur containing amino acids. The essential amino acids including threonine, lysine, valine, methionine, isoleucine, leucine, phenylalanine and Histidine was showed in Table (5). While the non-essential amino acid including Aspartic, arginine, serine, proline, glutamic, cystine, glycine, alanine and tyrosine were also presented in Table (5) as a concentration percentage. The result in the rice blends indicated that the essential amino acids were found in all weaning food blends. The Threonine was found in range 0.34 to $1.56 \%$. The leucin is the most amino acid found in the prepared weaning food ranged from 0.74 to $1.11 \%$. While the methionine was the lowest found with range of 0.23 to $0.45 \%$. The essential amino acids were higher than the control expect lysine because cereals are adequate in methionine but limiting in lysine. The non-essentials amino acids were found in wide range. The glutamic acid was the most found with range of 1.64 to $2.40 \%$. Followed in the descending order by aspartic acid was the most found with range of 1.07 to $1.56 \%$. However, the serine was the lowest of range 0.41 to $0.62 \%$.

The effective use of readily available and inexpensive sources of protein and micronutrients has become a major focus of research in recent years. Development of weaning foods from locally available and low cost raw materials is a constant challenge for developing countries. Weaning foods are generally produced by traditional techniques like milling, roasting, drying, and germination.

Table 5. Amino acid of weaning food cereal-legume

\begin{tabular}{lccccccc}
\hline Essential amino acids & Control /rice & \multicolumn{2}{c}{ Rice/soybean } & \multicolumn{2}{c}{ Rice/chickpeas } & \multicolumn{2}{c}{ Rice/peanut } \\
\cline { 2 - 9 } & $\mathbf{\%}$ & $\mathbf{\%}$ & Rank & $\mathbf{\%}$ & Rank & \% & Rank \\
\hline Threonine & 0.02 & 1.56 & 2 & 0.34 & 14 & 1.10 & 3 \\
\hline Lysine & 0.03 & 0.76 & 7 & 0.48 & 7 & 0.38 & 13 \\
\hline Valine & 0.05 & 0.70 & 10 & 0.49 & 6 & 0.53 & 10 \\
\hline Methionine & 0.40 & 0.45 & 15 & 0.24 & 17 & 0.23 & 16 \\
\hline Isoleucine & 0.08 & 0.63 & 11 & 0.39 & 12 & 0.38 & 12 \\
\hline Leucine & 0.04 & 1.11 & 4 & 0.74 & 4 & 0.79 & 4 \\
\hline Phenylalanine & 0.06 & 0.77 & 6 & 0.55 & 5 & 0.59 & 6 \\
\hline Histidine & 0.03 & 0.39 & 17 & 0.25 & 16 & 0.27 & 15 \\
\hline & Non-essential amino acids & & & & \\
\hline Aspartic & 0.12 & 1.56 & 2 & 1.07 & 2 & 1.10 & 3 \\
\hline Arginine & 0.08 & 1.07 & 5 & 0.90 & 3 & 1.11 & 2 \\
\hline Serine & 0.05 & 0.62 & 12 & 0.41 & 10 & 0.55 & 8 \\
\hline Proline & 0.06 & 0.71 & 9 & 0.44 & 9 & 0.49 & 11 \\
\hline Glutamic & 0.19 & 2.40 & 1 & 1.64 & 1 & 2.09 & 1 \\
\hline Cystine & 0.48 & 0.44 & 16 & 0.29 & 15 & 0.21 & 17 \\
\hline Glycine & 0.05 & 0.62 & 12 & 0.40 & 11 & 0.59 & 6 \\
\hline Alanine & 0.06 & 0.73 & 8 & 0.48 & 7 & 0.54 & 9 \\
\hline Tyrosine & 0.04 & 0.58 & 14 & 0.39 & 12 & 0.49 & 11 \\
\hline
\end{tabular}


In the present scenario of convenience and newer products, we explored the possibility of using twin screw extruder for preparation of weaning foods from maize and chickpea. Effects of feed moisture, barrel temperature, and screw speed on the quality parameters of extrudates were studied. Extrudates produced at lower feed moisture, higher screw speed, and higher barrel temperature showed good physicochemical properties and higher protein and starch digestibility (Pedersen et al., 1989; Gomez M, Rooney L,1993; Njongmeta et al., 2003; Pobee et al., 2017 and Xia et al. 2018).

Pobee et al. (2017) used flour from broken rice fractions in combination with soybeans and dried mangoes to develop four weaning formulations. Rice-Soy Mango (RSM) was prepared with four different ratios including control RSM-0 with $75 \%$ rice, $25 \%$ soy and $0 \%$ mango flour, RSM-5 with $70 \%$ rice flour, $25 \%$ soybeans flours and $5 \%$ mango flour, RSM-10 with $65 \%$ rice flour, $25 \%$ soybeans flours and 10\% mango flour and RSM-15 with $60 \%$ rice flour, $25 \%$ soybeans flours and $15 \%$ mango flour.

All the three newly formulated rice-mango weaning food met the Estimated Average Requirement (EAR) for energy (393.71-403.25 $\mathrm{KCal} / 100 \mathrm{~g})$, protein (10.7-15.24 g/100 g), carbohydrates $(68.44-73.87 \mathrm{~g} / 100 \mathrm{~g})$, zinc (8.67$10.84 \mathrm{mg} / \mathrm{d}$ and vitamin C (13.96-17.79 mg/100 g) levels but not for iron (3.99-7.61 mg/100 g), fat $(6.22-7.61 \mathrm{~g} / 100 \mathrm{~g})$ and calcium $(87.2-111.7 \mathrm{mg} / 100$ g). The beta-carotene levels ranged from 74.8 to $346.6 \mu \mathrm{g} / 100 \mathrm{~g}$ and showed significant differences. The past profile for the blends with low amounts of mango (RSM-5 and RSM-10) had a similar profile as the control (RSM-0), while RSM-15 had a lower profile. Among the three newly formulated blends, RSM-10 had the highest peak viscosity (74.0 BU) and highest final viscosity of 107 BU. The RSM-5, RSM-10 and RSM-15 were all lighter than RSM-0, albeit not significant. Increasing the content of mango resulted in the flour blend becoming more yellow. Even though the sensory quality of RSM-5 was the most preferred, there was no significant difference $(p>0.05)$ observed between the sensory quality of all the three newly formulated products (RSM-5, RSM-10, RSM-15) (Pobee et al., 2017).

Ali et al.,(2017) prepared maize-chickpea extrudates and they found that the ratio of ingredients in the optimized weaning mix was $40 \%$ maize- chickpea extrudates, $35 \%$ skim milk powder, and $25 \%$ sugar $(\mathrm{w} / \mathrm{w})$. The nutrient content was in agreement with the standards described by prevention of food adulteration (PFA) with high protein and starch digestibility.

Sheriff (2015) prepared a novel formulation of weaning food based on fermented rice (Dikwa), banjara beans and Sesame in a 70:20:10 ratio. The results indicated an increase in the $\mathrm{Mg}(69.3 \pm 0.02)$
$\mathrm{Zn}(2.45 \pm 0.02)$ and $\mathrm{Fe}(6.34 \pm 0.01)$ levels of the weaning food blend. Low level of calcium (76.4 \pm $0.02)$ and sodium was recorded. The Riboflavin $(0.3254 \pm 0.00001)$ and thiamine $(0.6287 \pm 0.00001)$ level were higher compared to the control. The protein content was $(8.31 \pm 5.41)$, the moisture content $(2.86 \pm 1.91)$, while the fibre content was $(5.6 \pm 4.40)$. Carbohydrate content of the blend was lower than the commercial weaning food cerelac $\AA$ but was however higher than the Recommended Daily Allowance (RDA) for infants at weaning age. It can be concluded that; protein, moisture, fat and carbohydrate content, as well as mineral and Vitamin of the weaning food blend met the RDA value of infants (6 month to 1 year) and thus it can be used in the management of problems associated with protein - energy - malnutrition.

\section{CONCLUSION}

Weaning is a gradual process of introducing solids foods to an infant's diet, alongside breast milk from the age of six months, since the breast feeding along cannot meet the infant nutritional requirement. The aim of this study were to developed a weaning foods based on commonly consumed, low-cost food materials locally-available in market.

There is need to have maximum utilization of commonly available cheap cereals and legumes to formulate weaning foods that would be low in viscosity high in caloric density and adequate in necessary nutrient. The protein content of the weaning food blend from rice ranged from $(7.90 \%$ to $10.70 \%$ ) and is the best of control. There is an increase in vitro protein digestibility in the weaning food blends from rice, and this is as a result of reduction in the level of anti-nutritional factor during formation. The results of the sensory evaluation shown that the best blends were contained rice/peanut and rice/ chickpeas but rice/ soybean was lower acceptability.

\section{RECOMMENDATIONS}

- It is recommended that infants feed on this formulation be breast feed for at least 2 years, as the formulation is intended to act as supplement to breast milk.

- Mothers can be advised to prepare these kinds of complementary foods hygienically for their weaning babies. This will go a long way in helping them out of the more expensive commercial formulae as well as improving their infants feeding. This could easily be achieved since all the food materials can be obtained locally and cheaply too.

- It is recommended mixing cereals with legumes because cereals such as maize, the main source of calories in the diet, are adequate in methionine and a good source of B-complex vitamins while 
legumes such as soy bean, peanut and chick peas are rich in lysine.

- It is recommended to cook, soak and roasting cereals and legumes to reduce the anti-nutritional factor and increase protein digestibility.

\section{REFERENCES}

Ahmed MB, Hamed RA, Ali ME, Hassan AB, Babiker EE (2006). Proximate composition, antinutritional factors and protein fractions of guar gum seeds as influenced by processing treatments. Pakistan Journal of Nutrition 5(5):481-484.

Ali S, Singh B, Sharma S (2017). Development of High- quality weaning food based on maize and chickpea by twin- screw extrusion process for low- income populations. Journal of Food Process Engineering 40(3): 1111-12500.

Anderson S (2007). Determination of fat, moisture, and protein in meat and meat products by using the FOSS FoodScan near-infrared spectrophotometer with FOSS artificial neural network calibration model and associated database: collaborative study. Journal of AOAC International 90(4):1073-1083.

Arber A (2010). The Gramineae: a study of cereal, bamboo and grass. Cambridge University Press18(5): 410-483.

Davies N, Reid H (1979). An evaluation of the phytate, zinc, copper, iron and manganese contents of, and $\mathrm{Zn}$ availability from, soyabased textured-vegetable-protein meatsubstitutes or meat-extenders. British Journal of Nutrition 41(3):579-589.

Embaby HE-S (2010). Effect of soaking, dehulling, and cooking methods on certain antinutrients and in vitro protein digestibility of bitter and sweet lupin seeds. Food Science and Biotechnology 19(4):1055-1062.

Gairdner D, Pearson J (1998). Preterm-2Y Length= Weight $=$ Head Circumference Growth Chart. Welwyn Garden City: Castlemead Publications 13(4):1089-1999.

Gulzar M (2011). Evaluation of weaning foods formulated from germinated wheat and mungbean from Bangladesh. African journal of food science 5(17): 897-903.

Hamerstrand G, Black L, Glover J (1981). Main content area Trypsin inhibitors in soy products: modification of the standard analytical procedure. Cereal Chemistry 58(1): 42-45.

Hooda S, Jood S (2005). Organoleptic and nutritional evaluation of wheat biscuits supplemented with untreated and treated fenugreek flour. Food Chemistry 90(3): 427435.

Hulse J (1989).Nature,composition and utilization of grain legumes. Uses of tropicl grain legumes 27 (11): 377-395.
Ijarotimi O, Famurewa J (2006). Assessment of chemical compositions of soybean supplemented weaning foods and nutritional knowledge of nursing mothers on their utilizations. Pak J of Nutr 5(3): 218-223.

Iqbal A, Ateeq $\mathrm{N}$, Khalil IA, Perveen S, Saleemullah S (2006). Physicochemical characteristics and amino acid profile of chickpea cultivars grown in Pakistan. Journal of Foodservice 17(2): 94-101.

Isaac AT, Koleosho A (2012). Effects of Processing Method on the Nutrients' Composition of Maize/Soya Complementary Food. J Pharm Biol Sci 4(1): 39-43.

Megat Rusydi M, Noraliza C, Azrina A, Zulkhairi A (2011). Nutritional changes in germinated legumes and rice varieties. International Food Research Journal 18(2):703-713.

Naczk M, Shahidi F (2004). Extraction and analysis of phenolics in food. Journal of Chromatography A 1054(1-2):95-111.

Nithya K, Ramachandramurty B, Krishnamoorthy V (2007). Effect of processing methods on nutritional and anti-nutritional qualities of hybrid (COHCU-8) and traditional (CO7) pearl millet varieties of India. J Biol Sci 7: 643-647.

Njongmeta L, Ejoh R, Mbofung C, Verhoef H, Nout $M$ (2003). Weaning practices in the Adamawa province of Cameroon. In second international conference on food-based approaches for a Healthy Nutrition of West Africa, Ouagadougou, Burkina Faso 60(7): 219-228.

Onweluzo J, Nwabugwu C (2009). Development and evaluation of weaning foods from pigeon pea and millet. Pakistan journal of nutrition 8(6):725-730.

Osman MA (2007). Effect of different processing methods, on nutrient composition, antinutrional factors, and in vitro protein digestibility of Dolichos lablab bean. Lablab purpuresus (L) Sweet]. Pakistan Journal of Nutrition 6(4): 299-303

Pedersen B, Hansen M, Munck L, Eggum BO (1989). Weaning foods with improved energy and nutrient density prepared from germinated cereals: 2. Nutritional evaluation of gruels based on barley. Food Nutr Bull 11(2): 4652.

Pobee R, Johnson P, Akonor P, Buckman S (2017). Nutritional, pasting and sensory properties of a weaning food from rice (Oryza sativa), soybeans (Glycine max) and kent mango (Mangifera indica) flour blends. African Journal of Food, Agriculture, Nutrition and Development 17(1): 11533-11551.

Prakash V, Prakash J (1999). In vitro protein digestibility of legumes cooked with spices. Food/Nahrung 43(1):19-21. 
Sharma S, Singh A, Sharma U, Kumar R, Yadav N (2018). Effect of thermal processing on anti nutritional factors and in vitro bioavailability of minerals in desi and kabuli cultivars of chick pea grown in North India. Legume Research: An International Journal 41(2):267-274.

Sheriff M (2015). Effects of Fortification of Rice with Banjara Beans and Sesame on Chemical Composition, Mineral Ele-ments and Vitamin Contents of a Complementary Meal. EC Nutrition 1(1):35-40.

Gomez M, Rooney L (1993). Production and nutritional value of weaning foods from mixtures of pearl millet and cowpeas. Cereal chemistry1(1): 0009-0352.

Tran TU, Suzuki K, Okadome H, Ikezaki H, Homma S, Ohtsubo Ki (2005). Detection of changes in taste of japonica and indica brown and milled rice (Oryza sativa L.) during storage using physicochemical analyses and a taste sensing system. Journal of agricultural and food chemistry 53(4):1108-1118.

Tsai C-Y, Dalby A, Jones R (1975). Lysine and tryptophan increases during germination of maize seed. Cereal Chemistry 52:356-360.
Udensi E, Odom T, Nwaorgu O, Emecheta R, Ihemanma $C$ (2012). Production and evaluation of the nutritional quality of weaning food formulation from roasted millet and Mucuna cochinchinesis. Sky Journal of Food Science 1(1):1-5.

Walker AF (1990). The contribution of weaning foods to protein-energy malnutrition. Nutrition research reviews 3(1): 25-47.

Wang N, Lewis M, Brennan J, Westby A (1997). Effect of processing methods on nutrients and anti-nutritional factors in cowpea. Food chemistry 58(1-2): 59-68.

Wondimu A, Malleshi NG (1996). Development of weaning foods based on malted, popped, and roller-dried barley and chickpea. Food and Nutrition Bulletin -United Nations University 1(7). 169-176.

Xia Y, et al. (2018). Breastfeeding, weaning, and dietary practices during the Western Zhou Dynasty (1122-771 BC) at Boyangcheng, Anhui Province, China. American journal of physical anthropology 165(2): 343-352.

Zaker A (2017). Studies on isolation and characterization of some important nutraceutical components from Orange waste and its exploration in weaning food. Vasantrao Naik Marathwada Krishi Vidyapeeth, Parbhani 1:145.

Zambrano F, Despinoy P, Ormenese R, Faria E (2004). The use of guar and xanthan gums in the production of 'light'low fat cakes. International journal of food science \& technology 39(9): 959-966. 


\section{الملخص العربى}

\section{اعداد وتقييم بعض اغذية الفطام المحضرة من الارز والبقوليات}

\section{تسبي محمد رشاد لطفي، استر فيكتور عبد النور، مروة زكي محفوظ، اسماء خالا شفيق}

قسم الاقتصاد المنزلي، كلية التربية النوعية، جامعة الاسكندرية

الفطام هو عملية تدريجية لإدخال الأطعمة الصلبة إلى النظام الغذائي للرضيع، جنبا إلى جنب مع حليب التـدي

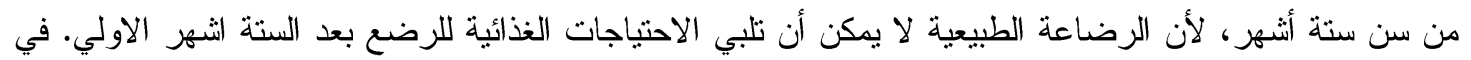

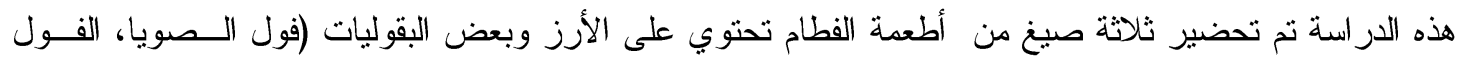

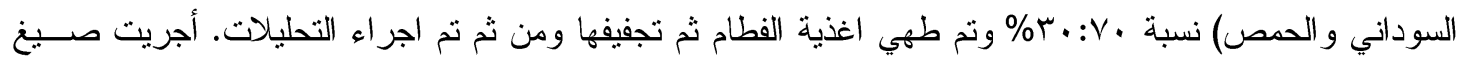
الفطام لتلبي الاحتياجات الضرورية للرضيع من الحمض الأميني وتلبية احتياجاته من الطاقة والبروتين وفقاً لتوصية

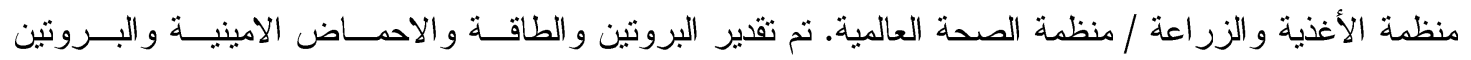

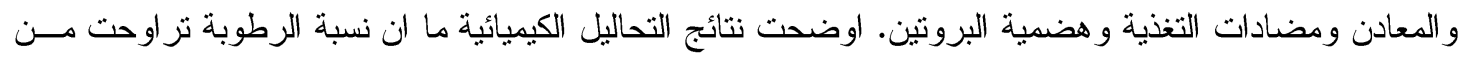

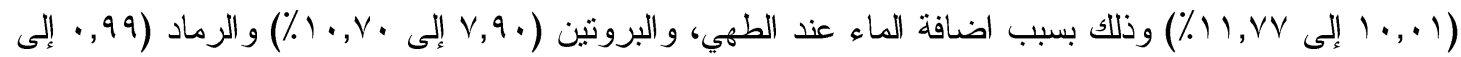

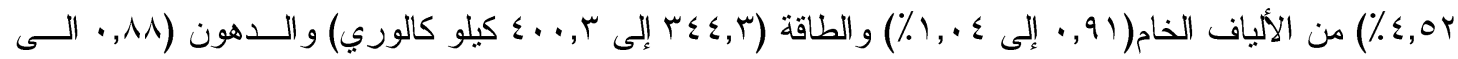

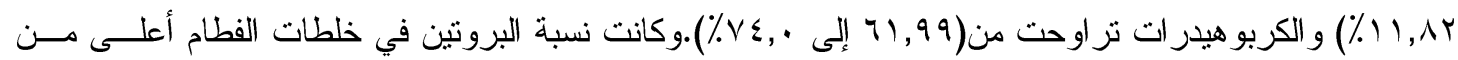
المجموعة الضابطة و الكونتزول عبارة عن الارز دون اضافة البقوليات.

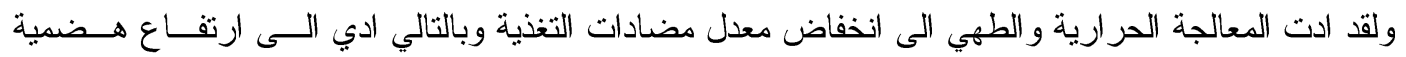

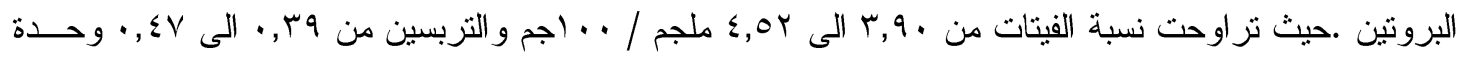

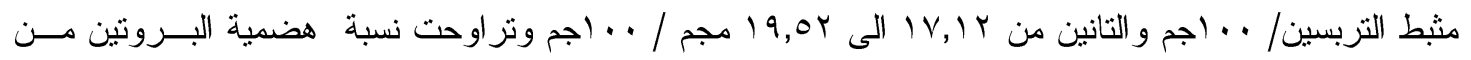

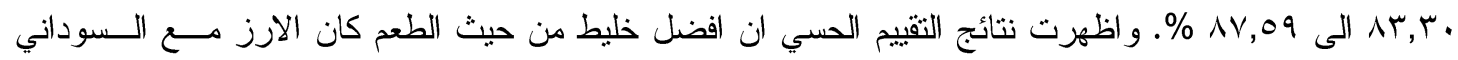

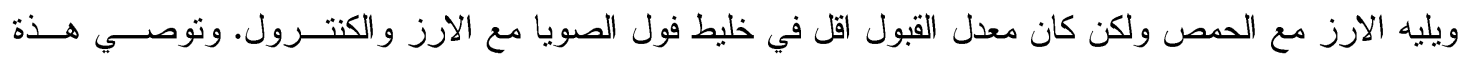
الدر اسة الى خلط الحبوب مع البقوليات لتحقيق افضل نكامل من حيث الاحماض الامينية وتحسين جودة البروتين. 